\title{
PÅLITELIGHETEN AV SELVRAPPORTERT STOFFBRUK BLANT UNGDOM
}

Av Ragnar Hauge og Ole Nordlie

\section{Innledning}

En sentral oppgave innenfor narkotikaforskningen er å kartlegge omfanget av og endringene i narkotikabruk i befolkningen. Slike opplysninger er ikke minst av betydning for det offentliges planlegging og iverksetting av tiltak med sikte på å motvirke narkotikabruken.

A skaffe data som kan belyse dette byr imidlertid på store problemer. En mulig fremgangsmåte kunne være å innhente data fra de forskjellige organer som kommer i kontakt med narkotikabrukere - enten det nå er strafferettsapparatet, helsevesenet, sosialetaten eller andre. Mange av disse organene fører imidlertid ingen løpende statistikk over de narkotikabrukere de er i kontakt med. Selv om de hadde kunnet gi statistiske oppgaver ville det budt på problemer å samordne dem fordi mange narkotikabrukere er i kontakt med forskjellige organer og man ville derfor fått en rekke dobbelttellinger.

Det eneste av disse organene som gir statistiske oppgaver er strafferettsmyndighetene. Gjennom kriminalstatistikken gis det oppgaver over etterforskede forbrytelser, foruten siktelser og reaksjoner for forbrytelser vedrørende ulovlig omgang med narkotika. Disse opplysningene er en av de viktigste kilder til informasjon om utbredelse og utvikling i narkotikabruk. Kriminalstatistikken har imidlertid sine klare begrensninger. For det første omfatter den bare forbrytelser mot narkotikalovgivningen, og ikke de tilfelle som rubriseres som forseelser. Dernest er forutsetningen for å bli registrert at politiet har fått kjennskap til saken - og svært mange tilfelle av bruk og andre former for ulovlig omgang med narkotika blir utvilsomt aldri kjent for politiet.

På grunn av de problemer som er knyttet til kriminalstatistikkens data som mål på utbredelsen og utviklingen av narkotikabruk, har man i utstrakt grad benyttet seg av undersøkelser av selvrapportert narkotikabruk. Slike undersøkelser gir mulighet for å ta for seg representative utvalg av befolkningen og kartlegge utbredelsen av narkotikabruk gjennom intervjuer eller spørreskjema uavhengig av hvorvidt bruken er kjent av offentlige organer eller ikke.

For Oslos vedkommende har Statens institutt for alkoholforskning siden 
1968 foretatt slike undersøkelser om bruken av forskjellige avhengighetsskapende og berusende stoffer. Opplysningene er innsamlet ved at det hver vår er sendt spørreskjemaer til et representativt utvalg av de unge i alderen 15-21 år som er registrert som bosatt i Oslo. (Irgens-Jensen 1982).

Også mot disse undersøkelsene kan det imidlertid rettes innvendinger av metodisk art. For det første er det ved selvrapporteringsundersøkelser et betydelig antall som ikke besvarer spørreskjema. I Oslo-undersøkelsene har andelen ubesvarte gjennomgående ligget på omlag 30 prosent. Dersom de som av en eller annen grunn ikke svarer skiller seg fra de øvrige, vil følgelig tallangivelser basert på de svar som kommer inn gi et skjevt bilde av de faktiske forhold.

Det har f. eks. vært hevdet at langtkomne stoffmisbrukere sjeldnere enn andre vil besvare slike spørsmål - fordi de ikke ønsker å svare eller fordi deres boforhold vil være så ustabile at man ikke får tak i dem. Dersom dette er tilfelle, vil resultatene innebære en underrapportering $\mathrm{i}$ forhold til den faktiske utbredelsen av stoffbruk.

Det har også vært hevdet at det blant dem som unnlater å svare vil være en overrepresentasjon av personer som ikke har brukt narkotiske stoffer, fordi disse vil oppleve spørsmålene som irrelevante for seg. I så fall vil resultatet av undersøkelsen bli en overrapportering i forhold til den faktiske stoffbruk.

Et annet viktig spørsmål i forbindelse med slike undersøkelser er hvorvidt svarpersonerne svarer æerlig eller ikke. Selv om spørreskjemaene er anonyme kan det tenkes at noen, ikke minst fordi stoffbruk er straffbart, unnlater å oppgi at de har brukt narkotiske stoffer eller oppgir en lavere bruk enn den faktiske. Det motsatte kan også tenkes - at ikke-brukere av en eller annen grunn oppgir at de har brukt narkotika, eller at brukerne oppgir et høyere forbruk enn det faktiske.

Betydningen av slike feilkilder vil være forskjellig, alt etter formålet med undersøkelsen. Dersom hovedformålet er å beregne omfanget av bruk av narkotiske stoffer på et gitt tidspunkt, vil feilkildene kunne være av vesentlig betydning. Imidlertid vil feilkildene være av mindre betydning dersom formålet er å belyse utviklingen over tid. Ved å benytte samme fremgangsmåte ved datainnsamlingen fra det ene året til det andre, kan man anta at feilkildene vil være konstante. Selv om anslagene over narkotikabruken på grunnlag av hver enkelt undersøkelse ikke er korrekte, vil de utviklingstendenser en kommer frem til - hvorvidt stoffbruken øker eller avtar og størrelsen av de relative endringer - kunne være korrekte.

Uansett hva formålet måtte være, er det likevel av sentral betydning å få kunnskap om hvorvidt slike undersøkelser gir et korrekt bilde av om- 
fanget av narkotikabruk i en befolkning. $\mathrm{Og}$ - dersom dette ikke er tilfelle, hvorvidt resultatene tenderer til å overdimensjonere eller underdimensjonere bruken.

I det følgende skal vi se nærmere på en undersøkelse som ble foretatt med sikte på å teste påliteligheten av slike selvrapporteringsundersøkelser av stoffbruk.

\section{Metode}

En mulig fremgangsmåte for å teste påliteligheten vedrørende selvrapporteringsundersøkelser av stoffbruk er å benytte metoden overfor en gruppe personer hvis stoffbruk på forhånd er kjent.

En slik gruppe er de som er straffet eller gitt påtaleunnlatelse for overtredelse av narkotikalovgivningen. På grunn av de strenge bevis som kreves for å bli straffet, kan man gå ut fra at de vil være skyldige. Fordi det store flertall av siktelsene gjelder bruk - oftest i kombinasjon med besittelse og i visse tilfelle også import eller omsetning av narkotika - kan en regne med at de aller fleste vil være brukere av narkotika. Videre kan man, fordi politiets og rettsapparatets virksomhet i regelen ikke vil være rettet mot de rene bagatellsaker, dessuten regne med at det gjennomgående vil være tale om et forholdsvis høyt forbruk.

Ved å velge en gruppe personer som er straffet eller gitt påtaleunnlatelse for narkotikalovbrudd som undersøkelsesobjekter vil man derfor være sikret en gruppe som har eller har hatt et relativt høyt forbruk av narkotiske stoffer. Dersom man samtidig med denne gruppen også undersøker et representativt utvalg av den samme befolkning som lovovertrederne er rekruttert fra, vil man kunne få en gruppe som kan tjene som sammenlikningsgrunnlag. For Oslo's vedkommende har man gjennom de årlige ungdomsundersøkelsene en slik kontrollgruppe. Det ville derfor være naturlig å avgrense lovbrytergruppen etter de samme kriterier som de unge til Oslo-undersøkelsen og å benytte samme fremgangsmåte ved begge undersøkelser.

Etter søknad fra Statens institutt for alkoholforskning ga Justisdepartementet tillatelse til at de samme spørreskjemaer som blir benyttet i Osloundersøkelsen, skulle kunne sendes til samtlige unge født 1961-1966 bosatt i Oslo som var domfelt eller gitt påtaleunnlatelse, hadde vedtatt forelegg eller fått saken avgjort ved oversendelse til barnevernsnemnd for narkotikaovertredelse i medhold av straffeloven eller legemiddelloven. Dette omfatter altså både de som er registrert for forbrytelser og forseelser. Oslo politikammer påtok seg å sette opp en navneliste på grunnlag av narkotikasek- 
sjonens register og å forestå utsendelsen av spørreskjema og purreskriv til personene på denne listen.

Det viste seg at det i alt var 316 unge i politiregisteret som oppfylte utvalgskriteriene. I følge Statistisk årbok for Oslo 1980 var det noe i overkant av 30000 ungdommer i de aktuelle årskull som var bosatt innenfor kommunegrensene. Dette betyr at de registrerte ungdommene tilsvarte omtrent én prosent av samtlige.

Av de registrerte var det seks personer som var født på en slik dato at de var trukket ut i det ordinære Oslo-utvalget og som derfor ble utelatt fra politiregisterutvalget. Det utvalg som ble tilsendt spørreskjema kom følgelig til å bestå av 310 personer. Tabell 1 viser fordelingen av disse på fødselsår og kjønn.

Tabell 1. Utvalget av straffbare for narkotikaovertredelser etter straffeloven eller legemiddelloven pr. februar 1982 blant ungdom bosatt i Oslo fordelt på kjønn og fødselsår.

\begin{tabular}{lccr} 
Fødselsår & Gutter & Jenter & Total \\
\hline 1961 & 97 & 19 & 116 \\
1962 & 69 & 15 & 84 \\
1963 & 46 & 12 & 58 \\
1964 & 29 & 3 & 32 \\
1965 & 18 & 1 & 19 \\
1966 & 1 & 0 & 1 \\
\hline Tilsammen & 260 & 50 & 310
\end{tabular}

Spørreskjemaene til begge utvalg ble sendt ut i februar-mars 1982, riktignok med en liten tidsdifferanse, men såpass liten at den ikke skulle ha særlige virkninger for eventuelle forskjeller i svarprosenten utvalgene imellom. Selv om utsendelsen av skjemaene til de politiregistrerte ble foretatt av politiet, ble prosedyren for utsendelsen gjort så lik som mulig. Pakkingen av begge forsendelsene ble foretatt ved Statens institutt for alkoholforskning og politiet ble gitt instruksjon om tidsdifferansen mellom utsendelse av spørreskjema og purrebrev. Siden spørreskjemaene til begge grupper var identiske og anonyme, ble det ene settet med spørreskjemaer påsatt instituttets stempel slik at en kunne holde svarpersonene fra de to utvalgene fra hverandre. ${ }^{1}$ )

1) Vi vil takke politiinspektør Arne Huuse og politiavdelingssjef Torleif Brandsness ved narkotikaseksjonen ved Oslo politikammer for velvillig bistand. 


\section{Betydningen av bortfallet}

Som vi var inne på innledningsvis, ligger antakelig en av de vesentligste feilkilder ved selvrapporteringsundersøkelser av narkotikabruk i at de som unnlater å svare kan skille seg systematisk ut fra dem som svarer. Dette kan resultere $\mathrm{i}$ at beregningene av omfanget av bruken på basis av svarene blir for høyt dersom det er ikke-brukerne som i særlig grad unnlater å svare, eller for lavt dersom det er brukerne som unnlater å svare.

I og med at utvalget fra narkotikaregisteret representerer en gruppe ungdom som må antas å være storbrukere av narkotika, har vi en mulighet til å belyse hvorvidt det blant disse er en overrepresentasjon av personer som unnlater å svare på spørreskjemaer. Dersom dette er tilfelle, skulle vi vente å finne en lavere svarfrekvens blant de politiregistrerte enn i Oslo-utvalget.

Som nevnt omfatter politiregisterutvalget 310 personer, mens Oslo-utvalget omfattet 1102 personer. Tabell 2 viser bortfallet i de to utvalg. Dersom man beregner svarprosenten som forholdet mellom utsendte og innkomne,

Tabell 2. Utvalg og bortfall $\mathrm{i}$ henholdsvis politiregisterutvalget og Osloutvalget 1982 .

\begin{tabular}{lcc} 
& $\begin{array}{c}\text { Oslo- } \\
\text { utvalget }\end{array}$ & $\begin{array}{c}\text { Politiregister- } \\
\text { utvalget }\end{array}$ \\
\hline Utsendte skjema & 1102 & 310 \\
Retur fra postverket & 22 & 35 \\
Netto ut & 1080 & 275 \\
Inn & 749 & 105 \\
Utelatt p. g. a. feil/mangler & 6 & 1 \\
Inn besvart & 743 & 104 \\
\hline
\end{tabular}

brukbare skjemaer er svarfrekvensen blant de politiregistrerte 34 prosent mot 67 prosent i Oslo-utvalget. En del av bortfallet skyldes imidlertid at skjemaet ikke er kommet frem til adressaten, men returnert av postverket. I disse tilfellene har vedkommende ikke hatt mulighet til å besvare spørreskjemaet. Dersom man ser bort fra disse, blir svarfrekvensen henholdsvis 38 prosent i politiregisterutvalget og 69 prosent i Oslo-utvalget.

Uansett hvilken beregningsmåte en bruker, viser det seg altså at bortfallet blant de politiregistrerte er langt høyere enn i ungdomsbefolkningen generelt. Noe av denne forskjellen kan imidlertid føres tilbake til andre forhold enn forskjeller i innstilling til å svare på slike skjemaer. 
Som det fremgår av tabell 2 er frafallet på grunn av retur fra Postverket langt hyppigere i politiregisterutvalget enn i det ordinære ungdomsutvalget. Dette kan skyldes at unge storbrukere av narkotika sjeldnere melder flytting til folkeregisteret og oftere befinner seg i fengsel eller behandlingsinstitusjon enn andre ungdommer, eller at de lever et mer omstreifende liv enn hva som er vanlig. Det faktum at den enkelte ikke lenger bor på den oppgitte adresse, gjelder antakelig for enda flere tilfelle enn i de hvor skjemaene kom i retur. Det er grunn til å tro at det i regelen vil være foreldre eller foresattes adresse som er notert i politiregisteret. I en del tilfelle hvor ungdommen ikke lenger er bosatt i foreldrehjemmet fordi han eller hun er flyttet, er anbrakt i institusjon eller har ukjent adresse, vil foreldrene antakelig hverken returnere skjemaet eller forsøke å ettersende det. Dette gjelder ikke minst når det er tale om en trykksakforsendelse fra et forskningsinstitutt som i dette tilfelle. Det er derfor mulig at en del av forskjellene i svarfrekvens kan forklares ved at færre av de politiregistrerte fikk skjemaet - og dermed hadde mulighet til å svare.

Et annet forhold av betydning for svarfrekvensen ligger i forskjellene i kjønnssammensetningen mellom de to utvalgene. Oslo-utvalget, som et representativt utvalg, besto av tilnærmelsesvis like mange gutter og jenter innenfor hver av de seks årsklassene. I utvalget av politiregistrerte derimot, var det - slik det fremgikk av tabell 1 - en betydelig overvekt av gutter. Erfaringsmessig er svarfrekvensen høyere blant jenter enn blant gutter. Dette var også tilfelle i Oslo-undersøkelsen i 1982. Mens 72 prosent av jentene besvarte skjemaet, gjaldt det samme bare 62 prosent av guttene. Dersom en justerer for forskjeller i kjønnssammensetningen mellom de to utvalg, er følgelig forskjellen i svarfrekvens noe mindre enn det vi fant i tabell 2.

Forskjellen i kjønnssammensetning mellom de to utvalgene og mindre aktuelle adresser for de som inngår i politiregisterutvalget enn de som inngår i Oslo-utvalget, kan utvilsomt forklare noe av forskjellene i svarfrekvens mellom de to utvalg. Likevel er det antakelig grunn til å hevde at langt fra hele forskjellen kan bortforklares. Den mest holdbare konklusjon synes derfor å være at undersøkelsen synes å vise at storbrukere av narkotika har en noe mindre tendens til å besvare slike spørreskjemaer enn hva som er tilfelle i ungdomsbefolkningen generelt.

Det samme har man funnet også i andre undersøkelser. I en undersøkelse av Habermann m. fl. (1972) fant man en høyere stoffbrukerfrekvens blant elevene i en »High school « - populasjon som var borte fra skolen ved gjennomføringen av en stoffbruksundersøkelse. Også Goldstein m. fl. (1970) fant en overrepresentasjon av storbrukere $\mathrm{i}$ frafallet. 


\section{Påliteligheten av svarene}

Den andre mulige sentrale feilkilde ved selvrapporteringsundersøkelser av stoffbruk knytter seg til spørsmålet om hvorvidt de som besvarer skjemaene også svarer ærlig. I og med at politiregisterutvalget omfatter personer som er straffet eller gitt påtaleunnlatelse for narkotikalovbrudd, burde man blant disse finne en meget høy andel av personer som oppga å ha brukt de forskjellige stoffene. I tabell 3 er gjengitt antall personer fra politiregisterutvalget som har brukt de ulike stoffene.

Tabell 3. Svarpersonene fra politiutvalget etter hvorvidt de oppgir å ha brukt de forskjellige stoffer.

\begin{tabular}{lrrrr} 
& Ja & Nei & Ubesvart & Total \\
\hline Brukt hasjisj/marihuana & 102 & 2 & - & 104 \\
Brukt LSD & 36 & 67 & 1 & 104 \\
Brukt amfetamin eller liknende & 68 & 36 & - & 104 \\
Brukt heroin/morfin & 46 & 56 & 2 & 104 \\
Har sniffet & 74 & 30 & - & 104 \\
Har tatt stoff med sprøyte & 41 & 63 & - & 104 \\
\hline
\end{tabular}

Tabell 3 synes å bekrefte at andelen brukere av forskjellige stoffer er meget høy. Hele 102 av de 104, eller 98 prosent, oppgir at de har brukt cannabis. Bruken av såkalte harde stoffer ligger også høyt - 65 prosent har brukt amfetamin og 44 prosent heroin. Det er bare to av svarpersonene som oppgir at de ikke har brukt noen av stoffene. En nærliggende forklaring på dette kan være at de er straffet eller gitt påtaleunnlatelse fordi de har vært i besittelse av eller har omsatt stoff uten å ha brukt det selv.

På bakgrunn av svarene på spørsmål om bruk av forskjellige stoffer, er det grunn til å konkludere med at de storbrukere som besvarer slike spørreskjemaer gir relativt sannferdige svar når det gjelder å angi hvorvidt de har brukt de forskjellige stoffer eller ikke.

Det synes heller ikke å være noen tendens til å underrapportere stoffbruken. Når det gjaldt bruk av cannabis og amfetamin ble det nemlig stilt spørsmål om hvor mange ganger de hadde brukt stoffene. Det viste seg at av de 73 personer som svarte med en tallangivelse, var det 59 som oppga at de hadde brukt cannabis 100 ganger eller mer. Av de resterende 31 var det 26 som oppga at det var mer enn tre år siden første gang de hadde brukt stoffet og av disse oppga 21 å ha brukt stoffet i løpet av siste måned - de fleste samme dag eller dagen før. Det er derfor ingen overvurdering dersom man anslår tallet på dem som har brukt cannabis forholdsvis ofte over en 
lengre periode til minst 80 prosent av samtlige. Av de 68 som oppga å ha brukt amfetamin eller liknende stoffer ga 60 en tallangivelse. Av disse svarte 34 at de hadde brukt stoffet 10 ganger eller mer.

Ut fra disse svarene synes det å være grunn til å hevde at for de storbrukere som svarer på spørreskjemaet, er det ikke noen markert tendens til at de underrapporterer omfanget av stoffbruken.

Spørreskjemaet inneholdt også spørsmål om respondenten noen gang var blitt arrestert for befatning med narkotiske stoffer. Av de 104 svarpersonene var det 92 som svarte ja og 12 som svarte nei på dette spørsmålet. Å bli arrestert er imidlertid noe annet enn utvalgskriteriet som var at vedkommende skulle være straffet eller gitt påtaleunnlatelse. Noen få kan derfor opfylle utvalgskriteriet uten å være blitt arrestert. Svarfordelingen på dette spørsmålet er følgelig heller ikke urimelig - og det synes å underbygge sannferdigheten i svarene.

Også dette synes å være $\mathrm{i}$ samsvar med det man har funnet i andre undersøkelser. I en studie av tidligere behandlede heroinmisbrukere fant Bale m. fl. (1981) at av 95 personer som oppga å ha brukt heroin i løpet av siste uke, ga 81 urinprøver positivt utslag for morfin - som heroin omdannes til i kroppen - mens 14 urinprøver var negative. Av de 177 personene som oppga at de ikke hadde brukt heroin i løpet av siste uke, ga 39 urinprøver positivt utslag for morfin, mens 138 urinprøver var negative. For noen av dem hvor man ikke fant samsvar mellom svarene og urinanalysene kan imidlertid det manglende samsvar skyldes forhold ved selve analysemetodene. Andre studier hvor selvrapportering kriterietestes mot urinprøver peker også i retning af at selvrapportering har en relativt høy grad av pålitelighet. Se for eksempel Bale (1979), Ben-Yehuda (1980) eller Cox og Longwell (1974). I en undersøkelse av Benson og Holmberg (1980) kontrollerte man svarene mot registre $\mathrm{i}$ forskjellige behandlingsinstitusjoner for stoffmisbrukere, og fant at de som oppga et høyt forbruk av stoff i langt større utstrekning var registrert enn dem som oppga en lavere bruksfrekvens. Det synes derfor å være grunn til å konkludere med at det er grunn til å feste lit til de opplysningene som gis ved selvrapportering, både når det gjelder bruk/ikke bruk og frekvensen av narkotikabruk.

\section{Betydningen av bortfallet blant storbrukere}

På bakgrunn av det foregående må vi kunne konkludere med at når de politiregistrerte storbrukerne først besvarer spørreskjemaet, så svarer de også relativt sannferdig. Den vesentlige feilkilde ved selvrapporteringsundersøkelser av narkotikabruk synes derfor å ligge på et annet plan nemlig $\mathrm{i}$ at mange av storbrukerne ikke svarer. 
På bakgrunn av det foregånde er det imidlertid mulig å foreta anslag over hvor stort avvik frafallet av storbrukere vil medføre når det gjelder forholdet mellom den faktiske stoffbrukerfrekvens og den stoffbrukerfrekvensen en finner ved selvrapporteringsundersøkelser.

Som nevnt var det 38 prosent av de politiregistrerte som besvarte spørreskjemaet. Selv om svarprosenten antakelig ville ligget noe høyere dersom spørreskjemaet hadde nådd alle og kjønnssammensetningen hadde vært mer lik, vil vi likevel ta utgangspunkt i denne prosentsatsen. Det innebærer imidlertid at de beregnete avvikene vi kommer frem til med rimelighet må sees på som maksimumsavvik.

To typer av spørsmål i spørreskjemact gir mulighet for å finne frem til storbrukerne. For det første ble de unge spurt om de noengang var blitt arrestert for befatning med narkotiske stoffer. Som tidligere nevnt var det 92 , eller 88 prosent av de 104 politiregistrerte som besvarte skjemaet som oppga at de var blitt arrestert, mens det i Oslo-undersøkelsen var åtte av de 743 svarpersonene som svarte bekreftende på spørsmålet. Selv om det å bli arrestert ikke er det samme som å bli straffet eller gitt påtaleunnlatelse er det grunn til å tro at de to gruppene likner på hverandre. Når det gjaldt stoffbruk, viste de arresterte i Oslo-undersøkelsen seg å likne sterkt både

Tabell 4. Antall personer som har brukt ulike stoffer blant de arresterte i Osloundersøkelsen 1982, de arresterte i Oslo-undersøkelsen 1978-82, de arresterte blant respondentene fra politiregisterutvalget og blant alle respondentene i politiregisterutvalget.

Har brukt: Hasjisj LSD Amfetamin Opiat Sniffet Sprøyte

\begin{tabular}{|c|c|c|c|c|c|c|}
\hline $\begin{array}{l}\text { Arresterte i Oslo- } \\
\text { undersøkelsen } 1982 \\
(\mathrm{~N}=8)\end{array}$ & $\begin{array}{c}8 \\
100 \%\end{array}$ & $\begin{array}{c}3 \\
38 \%\end{array}$ & $\begin{array}{c}4 \\
50 \%\end{array}$ & $\begin{array}{c}4 \\
50 \%\end{array}$ & $\begin{array}{c}6 \\
75 \%\end{array}$ & $\begin{array}{c}4 \\
50 \%\end{array}$ \\
\hline $\begin{array}{l}\text { Arresterte i Oslo- } \\
\text { undersøkelsen } 1978-1982 \\
(\mathrm{~N}=46)\end{array}$ & $\begin{array}{l}45 \\
98 \%\end{array}$ & $\begin{array}{l}19 \\
41 \%\end{array}$ & $\begin{array}{l}27 \\
59 \%\end{array}$ & $\begin{array}{l}19 \\
41 \%\end{array}$ & $\begin{array}{l}32 \\
70 \%\end{array}$ & $\begin{array}{l}12 \\
26 \%\end{array}$ \\
\hline $\begin{array}{l}\text { Arresterte fra politi- } \\
\text { registerutvalg } \\
(\mathrm{N}=92)\end{array}$ & $\begin{array}{c}92 \\
100 \%\end{array}$ & $\begin{array}{l}34 \\
38 \%\end{array}$ & $\begin{array}{l}63 \\
68 \%\end{array}$ & $\begin{array}{l}43 \\
47 \%\end{array}$ & $\begin{array}{l}68 \\
74 \%\end{array}$ & $\begin{array}{l}39 \\
43 \%\end{array}$ \\
\hline $\begin{array}{l}\text { Alle respondenter i } \\
\text { politiregisterutvalg } \\
(\mathrm{N}=104)\end{array}$ & $\begin{array}{l}102 \\
98 \%\end{array}$ & $\begin{array}{l}36 \\
35 \%\end{array}$ & $\begin{array}{l}68 \\
65 \%\end{array}$ & $\begin{array}{l}46 \\
44 \%\end{array}$ & $\begin{array}{l}74 \\
71 \%\end{array}$ & $\begin{array}{l}41 \\
40 \%\end{array}$ \\
\hline
\end{tabular}


på de arresterte i politiregisterutvalget og på samtlige registrerte. Dette fremgår av tabell 4 som viser fordelingen av bruk av forskjellige stoffer for de åtte som oppga å være arrestert i Oslo-utvalget, de 104 som inngikk i politiregisterutvalget samt de 92 av disse som oppga å være arrestert. Vi har dessuten, for å få noe høyere tall, også sett på fordelingen blant de 46 personer som oppgir å være blitt arrestert i Oslo-undersøkelsen de siste fem år.

Det faktum at stoffbruken blant de arresterte i Oslo-undersøkelsen i hovedtrekk faller sammen med stoffbruken i politiregisterutvalget, skulle derfor tilsi at det å være arrestert er en relativt god indikator på storbrukere.

En del storbrukere vil imidlertid aldri bli arrestert. Gjennom spørreskjemaet har vi imidlertid mulighet til å kartlegge storbrukerne direkte på grunnlag av de svar de har gitt på spørsmålene om bruk av de forskjellige stoffene. Tabell 5 viser hvordan de 102 fra politiregisterutvalget og de 161 fra Oslo-utvalget som oppga at de hadde brukt ett eller flere av stoffene marihuana eller hasjisj, LSD, amfetamin og liknende stoffer eller opiater fordeler seg etter hvilke stoffer de har brukt, hvorvidt de har tatt stoff med sprøyte og endelig hvorvidt de har vært arrestert for stoffbruk.

Som det fremgår av tabellen har de politiregistrerte i langt høyere grad

Tabell 5. Brukere av narkotika etter hvilke kombinasjoner av stoffer de har brukt, hvorvidt de har tatt stoff med sprøyte og hvorvidt de er arrestert for befatning med narkotiske stoffer i henholdsvis politiregister-utvalget og i Oslo-utvalget.

$$
\begin{array}{cc}
\text { Politiregister-utvalget } & \text { Oslo-utvalget } \\
\text { Derav: } & \text { Derav: } \\
\text { med } & \text { med }
\end{array}
$$

Antall sprøyte arrestert Antall sprøyte arrestert

\begin{tabular}{lrrrrrr} 
LSD, Amf., Opiat, Hasj & 29 & 24 & 27 & 4 & 4 & 3 \\
LSD, Amf., Hasj & 6 & 2 & 6 & 4 & 0 & 0 \\
Amf., Opiat, Hasj & 15 & 12 & 14 & 6 & 1 & 1 \\
LSD, Hasj & 1 & 0 & 1 & 2 & 0 & 0 \\
Amf., Hasj & 18 & 3 & 16 & 10 & 2 & 0 \\
Opiat, Hasj & 2 & 0 & 2 & 0 & 0 & 0 \\
Amf. & 0 & 0 & 0 & 1 & 0 & 0 \\
Hasj, 100 ganger og mer & 22 & 0 & 19 & 18 & 0 & 4 \\
Hasj, 10-99 ganger & 7 & 0 & 5 & 44 & 0 & 0 \\
Hasj, 0-9 ganger & 2 & 0 & 2 & 72 & 0 & 0 \\
\hline Sum & 102 & 41 & 92 & 161 & 7 & 8 \\
\hline
\end{tabular}


Tabell 6. Prosentandeler av stoffbrukerne etter stoffbelastning.

\begin{tabular}{lcc} 
& Politiregister-utvalget & Oslo-utvalget \\
\hline 3 harde stoffer + hasjisj & 28 & 2 \\
2 harde stoffer + hasjisj & 21 & 6 \\
1 hardt stoff + hasjisj & 21 & 7 \\
1 hardt stoff & - & 1 \\
Hasjisj 100 ganger og mer & 22 & 11 \\
Hasjisj 10-99 ganger & 7 & 27 \\
Hasjisj 1-9 ganger & 2 & 45 \\
SUM $\%$ & 101 & 99 \\
N & 102 & 161 \\
\hline
\end{tabular}

enn de øvrige brukt andre stoffer enn cannabis og også tatt stoff med sprøyte. For å lette oversikten over stoffbelastningen blant stoffbrukerne i de to utvalgene, har vi i tabell 6 prosentuert kombinasjonsmulighetene. Som det fremgår av tabellen er det $\mathrm{i}$ begge utvalgene en del av stoffbrukerne som bare har brukt cannabispreparater. Dette gjelder omlag 31 prosent av de politiregistrerte og 83 prosent av de som har brukt stoff i Oslo-utvalget.

På grunnlag av denne oppsplittingen kan vi velge alternative definisjoner på storbrukere av narkotika. De mest nærliggende alternativene vil være: 1. Vedkommende må ha tatt stoff med sprøyte. 2. Vedkommende må ha brukt andre stoffer enn cannabis. 3. Vedkommende må ha tatt andre stoffer enn cannabis eller ha brukt cannabis 100 ganger eller mer. Nå vil kanskje noen innvende at selv om en har brukt cannabis mindre enn 100 ganger, så vil det være rimelig å kalle vedkommende for storbruker. I denne sammenhengen synes det imidlertid urimelig, fordi andelen av disse i politiregisterutvalget er så liten at de ikke kan benyttes til testing av svarfrekvensen i denne brukergruppen.

Med utgangspunkt i at svarfrekvensen var 38 prosent blant de politiregistrerte og tallangivelsene over personer som omafttes av de ulike storbrukerdefinisjonene blandt de 743 svarpersonene fra Oslo-undersøkelsen, kan vi foreta anslag over hvor mange storbrukere en kan forvente at det finnes blant de 1102 ungdommene i det opprinnelige trukne Oslo-utvalget. Beregningene foretas ved at antallet storbrukere funnet blant svarpersonene i Oslo-undersøkelsen divideres med $38 \mathrm{og}$ multipliseres med 100. Antallet storbrukere etter de ulike definisjonene blant de 743 svarpersonene og det beregnete antallet for det trukne utvalget på 1102 er gjengitt i tabell 7 .

Av tabellen fremgår at dersom en benytter kriteriet arrestert, er avviket 0.8 prosentenheter. Ved definisjonen tatt stoff med sprøyte er avviket 0.7 
Tabell 7. Antall og andel storbrukere - blant svarpersonene i Oslo-undersøkelsen 1982, beregnet anslag for det trukne utvalget og beregnet avvik i prosentenheter.

\begin{tabular}{lccc}
$\begin{array}{l}\text { Storbruker } \\
\text { definert som: }\end{array}$ & $\begin{array}{c}\text { Svarpersoner } \\
\text { Oslo 1982 } \\
(\mathrm{N}-743)\end{array}$ & $\begin{array}{c}\text { Beregnet anslag } \\
\text { trukket utvalg } \\
\text { (HN-1102) }\end{array}$ & $\begin{array}{c}\text { Beregnet } \\
\text { avvik }\end{array}$ \\
Arresterte & $8(1.1 \%)$ & $21(1.9 \%)$ & $(0.8 \%)$ \\
$\begin{array}{l}\text { Stoff m. sprøyte } \\
\text { Andre stoffer enn cannabis }\end{array}$ & $27(0.9 \%)$ & $18(1.6 \%)$ & $(0.7 \%)$ \\
$\begin{array}{l}\text { Andre stoffer eller } \\
\text { cannabis } 100 \text { ganger og mer }\end{array}$ & $45(6.0 \%)$ & $118(10.7 \%)$ & $(2.8 \%)$ \\
\hline
\end{tabular}

prosentenheter og ved definisjonen brukt andre stoffer enn cannabis er den 2.8 prosentenheter. Ved den videste definisjonen av storbruker som det er forsvarlig å benytte i denne sammenhengen - nemlig at vedkommende har brukt andre stoffer enn cannabis eller brukt cannabis 100 ganger eller mer - er avviket 4.7 prosentenheter.

Vi kan på dette grunnlag konkludere med at på grunn av overrepresentasjonen av storbrukere av narkotika blant dem som ikke besvarer spørreskjemaet, må stoffbrukerfrekvensen i Oslo-undersøkelsen - som i 1982 lå på 21.5 prosent - justeres opp med maksimalt 4.7 prosentenheter til maksimalt 26.2 prosent. Vi må med andre ord kunne slutte at frafallet av storbrukere vil ha en relativt begrenset betydning for resultatene av selvrapporteringsundersøkelser blant representative utvalg av de unge.

\section{Betraktninger og konklusjon}

I og med at vi i det foregående har konsentreret oss om storbrukere, kan vi ikke si noe om hvordan de med et mer moderat stoffbruk og dem som ikke har brukt stoff er representert $\mathrm{i}$ frafallet.

Innledningsvis ble det nevnt at dersom ikke-brukerne var underrepresentert blant dem som svarer, så vil brukerfrekvensen som resultat av selvrapporteringsundersøkelser ligge for høyt i forhold til den faktiske utbredelsen av stoffbruk. Dersom det forholder seg slik at ikke-brukerne faktisk også er underrepresentert blant dem som svarer, vil dette kunne oppveie underrepresentasjonen av storbrukerne blant svarerne, slik at brukerfrekvensen må justeres ned. En oppfølgingsundersøkelse blant ikke-svarere i Agder, utført av Arner, Duckert og Hauge (1980), kan gi grunn til å tro at det er en slik overrepresentasjon av ikke-brukere i bortfallet.

I denne undersøkelsen ble de som ikke hadde besvart det opprinnelige skjema bedt om å angi hvorvidt de noengang hadde brukt marihuana eller 
hasj og hvorfor de ikke hadde besvart det opprinnelige spørreskjemaet. Av de 74 som besvarte oppfølgingsskjemaet var det 68 som svarte at de aldri hadde brukt marihuana eller hasjisj, tre svarte bekreftende, mens tre lot spørsmålet stå ubesvart. Mens det var 10.7 prosent av de som besvarte det opprinnelige skjemaet som hadde brukt cannabis, gjaldt følgelig det samme bare 4.2 prosent av dem som besvarte spørsmålet i tilleggsskjemaet. En av de tre hovedgrunnene som ble oppgitt for ikke å ha svart på det opprinnelige skjemaet var at vedkommende ikke trodde svarene hadde noen interesse fordi han eller hun aldri hadde brukt stoff. Denne undersøkelsen kan med andre ord tyde på en overrepresentasjon også av ikke-brukere i bortfallet, noe som i tilfelle ville innebære at det forhøyete frafallet blant storbrukere delvis vil kunne oppveies av dette. I så fall vil den reelle brukerfrekvensen for narkotika i ungdomsbefolkningen ligge svært nær resultatene fra selvrapporteringsundersøkelsene som for Oslo's vedkommende var 21.5 prosent. Siden det imidlertid også finnes andre fortolkningsmuligheter av resultatene fra oppfølgningsundersøkelsen i Agder, skal vi ikke trekke konklusjonen for langt, men nøye oss med følgende:

Overrepresentasjonen av storbrukere av narkotika blant dem som ikke besvarer spørreskjema i Oslo-undersøkelsen medfører i uheldigste fall at brukerfrekvensen for stoff blant de aktuelle årskull Oslo-ungdommer ligger 4.7 prosent høyere enn de 21.5 prosent som ble målt ved Oslo-undersøkelsen 1982. Man må imidlertid ta i betraktning at storbrukere av narkotika sannsynligvis sjeldnere melder flytting til folkeregistreret og oftere befinner seg i fengsel eller behandlingsinstitusjon enn andre ungdommer, og at det $\mathrm{i}$ politiregisterutvalget var en overrepresentasjon av gutter som jo vanligvis har en noe lavere svarfrekvens enn jenter. Det gjør at størrelsen på avviket mellom den målte stoffbrukerfrekvensen og den faktiske utbredelsen av stoffbruk i befolkningen høyst sannsynlig vil være en del mindre enn de beregnete 4.7 prosent.

I tillegg kommer at det er grunn til å tro at også ikke-brukere av stoffer har en noe større tendens enn de øvrige til å unnlate å besvare slike spørreskjemaer. Også dette vil i tilfelle føre til at størrelsen på avviket vil bli noe redusert.

Selv om det altså er klare feilkilder ved undersøkelser av selvrapportert stoffbruk, synes disse likevel å gi et relativt pålitelig bilde av den faktiske utbredelse av stoffbruk i ungdomsbefolkningen. 


\section{REFERANSER}

Arner, O., M. Duckert \& R. Hauge: Ungdom og narkotika. En undersøkelse av stoffbruk og stoffbrukere. Universitetsforlaget, Oslo 1980.

Bale, R. N.: The Validity and Reliability of Self-Reported Data from Heroin Addicts: Mailed Questionnaires Compared with Face-to-Face Intervicws. The International Journal of the Addictions, vol. 14, 1979, s. 993-1000.

Bale, R. N., W. W. van Stone, T. M. J. Engelsing \& V. P. Zarcone: The Validity of Self-Reported Heroin Use. The International Journal of the Addictions, vol. 16, 1981, s. 1387-1398.

Benson, G. and M. B. Holmberg: The Validity of Coded Questionnaires in Drug Surveys. Department of Psychiatry I, University of Gothenburg, Sahlgren's Hospital, Gothenburg, Sweden, 1980.

Ben-Yehuda, N.: Are Addicts' Self-Reports to be Trusted? International Journal of the Addictions, vol. 15, 1980, s. 1265-1270.

Cox, T. J. \& B. Longwell: Reliability of Interview Data Concerning Current Heroin Use from Heroin Addicts on Methadone. International Journal of the Addictions, vol. 9, 1974, s. 161-165.

Goldstein, J. W., J. H. Korn, W. H. Abel \& R. M. Morgan: The Social Psychology and Epidemiology of Student Drug Use: A Report of the Carnegie-Mellom University Drug Use Research Project. Project No. MH-15805, National Institute of Mental Health 1970.

Habermann, P., E. Josephson, A. Zanes \& J. Elinson: High School drug behaviour: A methodological report on pilot studies: In S. Einstein and S. Allen (eds): Student Drug Surveys. Farmingdale, New York: Baywood 1972.

Irgens-Jensen, Olav: Bruk av stoffer blant ungdom i Oslo 1968-1982. Stoffmisbruk nr. 7/8, 1982, s. 15-20.

Forskningssjef Ragnar Hauge

Vitenskapelig assistent Ole Nordlic

begges adresse:

Statens institut for alkoholforskning

Dannevigsveien 10, Oslo 4. 